\title{
An Initial Screening Tool for water resource contamination due to development in the Olympic Park 2012 site, London
}

\author{
Marchant, A.P., Banks, V.J., Royse, K., Quigley, S.P., and Wealthall, G.P. \\ British Geological Survey, Kingsley Dunham Centre, Nicker Hill, Keyworth, Nr \\ Nottingham, NG12 5GG.
}

Corresponding Author: A. Marchant (email: a.marchant@bgs.ac.uk)

Keywords: Contaminated Land, Part IIa of the Environmental Protection Act (1990), Screening Tool, Groundwater, Surface Water, GIS

\begin{abstract}
.
Groundwater is the primary source of potable water in southeast England. Its protection in urban environments is of paramount importance. Following a scoping study the British Geological Survey (BGS) established a project to develop an initial screening tool (IST) to assist the planning community in the assessment of the potential risk to ground and surface waters from contaminants mobilised as a consequence of redevelopment. The tool has been designed in the context of the source-pathway-receptor paradigm that informs Part IIa of the UK Environmental Protection Act (1990). Building on the work of previous screening tools and in particular ConSEPT, a BGS contaminated site evaluation and prioritisation tool, the IST incorporates significant refinements to scoring methodologies and takes the prioritisation approach into the 3-D environment. Implemented as a customised GIS application and utilising surfaces extracted from 3-D geological modelling, the tool collates and interrogates a range of geoscientific information, including: contaminant scale, geological, historic land use, groundwater level and hydrogeological domain data. The IST facilitates the ranking of various proposed development scenarios through a semi-quantitative assessment of contamination potential, via a number of pollutant linkages, providing planners with reports on the type, spatial distribution and hazards associated with potential contaminant sources within their area. To achieve this, a range of evaluation factors applied to the sources, pathways and receptors are scored through a combination of spatial and attribute queries, then assessed on the basis of potential linkages. The initial research area selected for the application of the IST was the Olympic Park site, London.
\end{abstract}

\section{Introduction.}

Over $80 \%$ of the total public water supply in southeast England is derived from groundwater (Lloyd et al. 1998), thereby making groundwater protection a key issue in the development of the Thames Gateway, London. Subsequent to the announcement of the proposed redevelopment of the Thames Gateway area and in the context of a British Geological Survey (BGS) 5-year interdisciplinary applied 
research project, a scoping study to assess the geoscience needs of stakeholders in the Thames Gateway and establish how best to serve those requirements was commissioned (Royse 2005; Royse et al. 2005). An outcome from this study was a project to develop an initial screening tool (IST) to assist the planning environment in the assessment of the potential risk to groundwater and surface waters from contaminants mobilised by redevelopment in the Thames Gateway. The intent was that the IST should build on the work of previous screening tools which are based in a 2-D environment and therefore consider surface features only. When assessing risk to groundwater, 3-D information is critical and thus a key feature of the IST was that it should be compatible with the 3-D modelling environment in order to support decision-making with respect to the protection of groundwater for the benefit of the end-user community. Following the decision to host the 2012 Olympic Games in London, the Olympic Park site was selected for the creation of a pilot for the IST project. This selection was made for a number of reasons, including: the existence of detailed, BGS 3-D geological and hydrogeological models of the area; the existence of established working relations with the London Borough of Newham, and the high profile of the Olympic Park site.

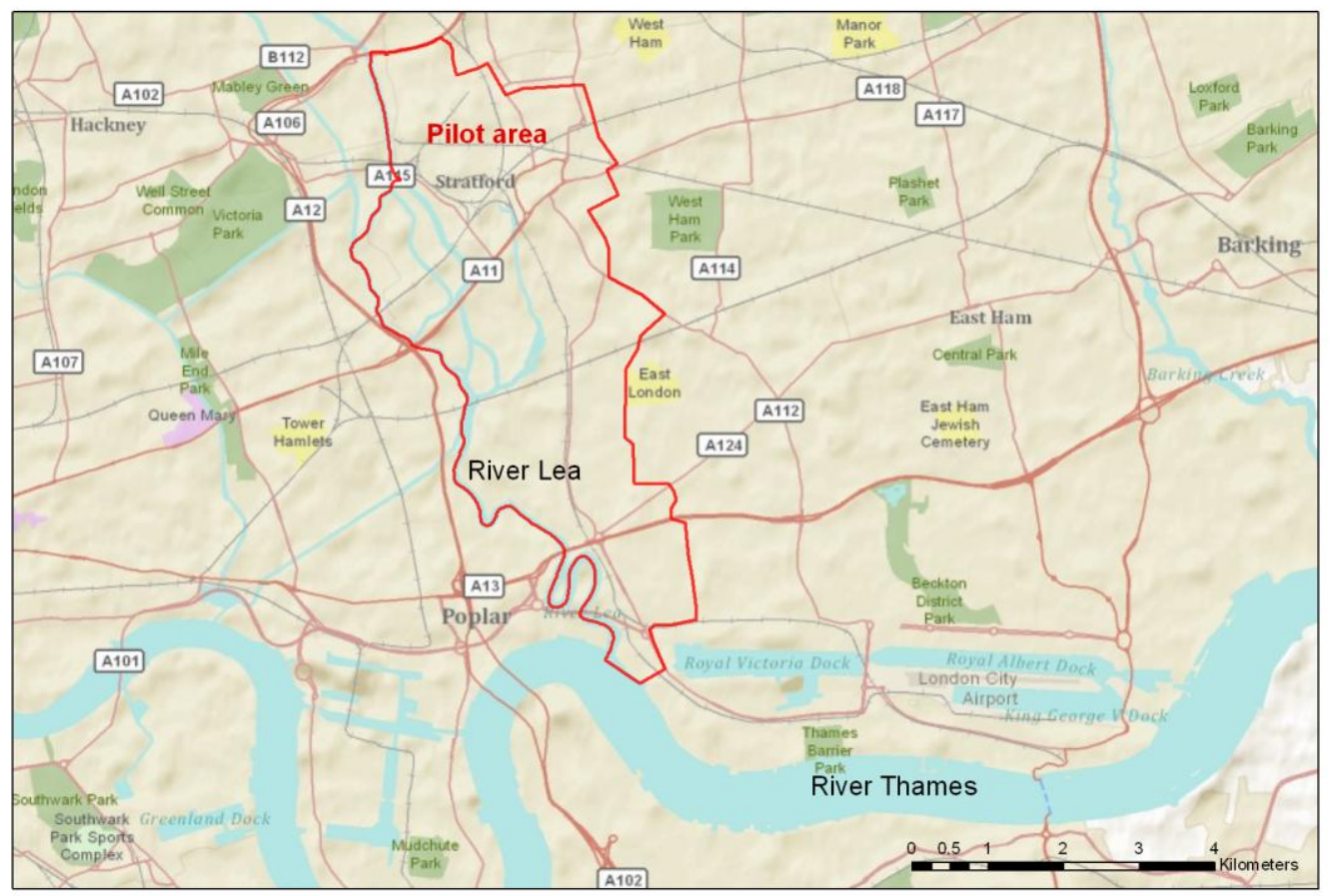

Figure 1: IST pilot area

Conceptual understanding of the Olympic Park site.

The Olympic Park site occupies land on the eastern side of the north to south-trending Lower Lea valley, extending from the River Thames in the south to Temple Mills in the district of Stratford in the north and between the districts of Bow in the west and West Ham in the east. The area is approximately $6 \mathrm{~km}$ in length, with a width that reaches slightly more than $2 \mathrm{~km}$ (Figure 1). Falling within the valleys of the rivers Lea and Thames, most of the land is relatively low lying and largely below 20m OD (Ordnance Datum Newlyn). Reflecting the topographical setting, the area is largely underlain by alluvial soils with river terrace deposits (Taplow Gravel Formation) 
forming the higher ground of the east and west valley sides. Geologically the area lies to the north of the axis of the London Syncline and this influences the distribution of the sub-surface, Palaeogene and Neogene solid geology with the older Lambeth Group strata that underlie the northern part of the research area, being progressively capped by the Thames Group (London Clay and Harwich formations) in a southerly direction. Deposits of the Cretaceous Chalk Group (primary aquifer) underlie the Palaeogene and Neogene strata at depth (Figure 2).
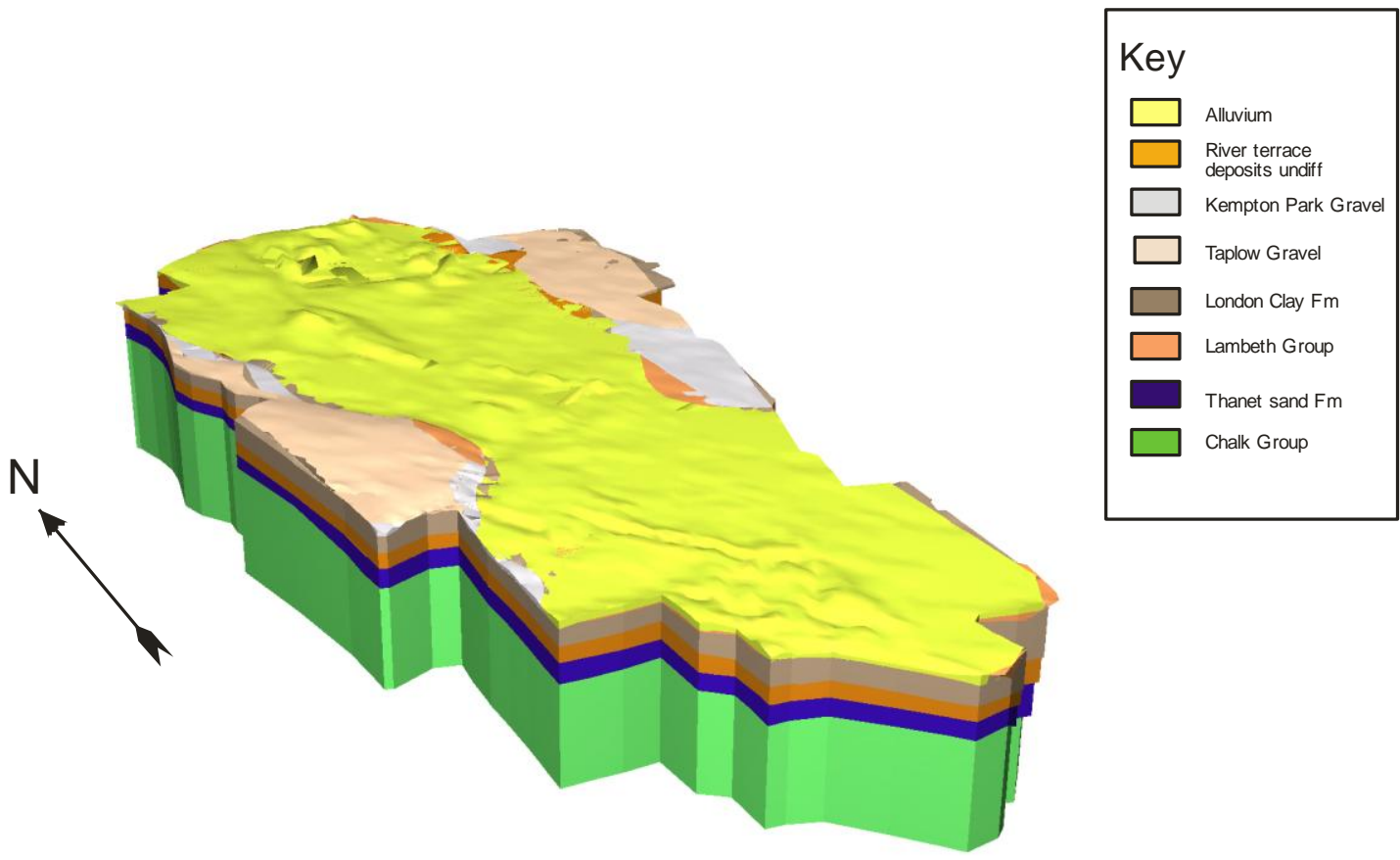

Figure 2: 3-D Geological model of the pilot area.

Significant areas of the superficial sequence are overlain by artificial deposits, variously classified as: infilled, worked, landscaped and made ground (McMillan and Powell 1999). The occurrence of the artificial deposits reflects the history of development of the Lea Valley and a legacy of this history is tracts of land that are potentially contaminated with a broad range of contaminants. The contaminants are best interpreted through an understanding of the history of the development the area. The River Lea, which once formed the boundary between Essex (to the East) and London (to the west) is reputed to have been navigable in Roman and Anglo-Saxon times (Weinreb and Hibbert 1983). At the time of Doomsday there were already eight water mills along this stretch of the River Lea. From medieval times to the present there were a number of phases of river improvement and it now comprises a network of canals. The area remained largely undeveloped until the late Middle Ages with much of the area of the Olympic Park site being given over to the West Ham Abbey Marsh (the Abbey was founded in 1134 and dissolved in 1538) with hop grounds to the north. Temple Mill on the northern boundary of the Olympic Park site was already in existence by this time. The famous Abbey Mills Pumping Station, a sewage pumping station, was established in 1865-8 as part of the main drainage scheme for London (Weinreb and Hibbert 1983) and the Three Mills Distillery was established from 1727 and was rebuilt in 1776. During the Middle Ages the river formed a conduit for human and animal waste (reflecting the outward migration of slaughter 
houses that had been banned from London) and the river began to be a focal point for the industries that started to spring up during the 1600 s, including silk weaving, calico printing, the manufacture of Bow porcelain, distilling and gun-powder making. Associated with improvements in transport and in particular with the coming of the railway (1839) the main wave of industrial development took place in the early to mid 1800s when the range of industries was expanded to include: tanning, flour mills, chemical works, ship building, asphalt works, maltings, manure works. A gas works site was established near the confluence of the River Lea with the River Thames and others were established farther north. It is very likely that waste from the gas works was deposited along the valley sides. Clearly the legacy of this history of industrial development is the likelihood of remnant contamination from multiple potential contaminant sources. Additionally, there are the issues associated with infilled docks and diverted water courses. Historically water courses were often modified, or maintained using old gas works waste. Infilled docks can be associated with a wide range of contaminants formerly associated with shipyards, including timber treatment products such as creosols.

Since 1967 and the establishment of the Lea Valley Regional Park there have been considerable efforts to improve the River Lea and its environ. The Regional Park Authority has a remit to develop and preserve leisure, recreation, sport, nature and ecology throughout the Park, and to regenerate derelict land and preserve the historic value of the area, which lies at the heart of the Olympic Park project. The value of the water resource has been realised and although direct abstraction from the Lea is restricted by the need to maintain minimum acceptable flows, a pumped storage reservoir has been constructed in the Lea valley (Sumbler 1996).

Chalk forms the main aquifer in the southeast of England and therefore is the key receptor in terms of the consideration of groundwater protection and the development of the IST. The chalk is capped by a sequence of solid and drift deposits. Understanding of the distribution and potential impacts of a number of geological features is essential to the protection of the aquifer. These include: distribution of karst features (commonly associated with the feather-edge of the Palaeogene and Neogene strata; Edmonds 1983; Edmonds et al. 1987); distribution of scour features (Ellison 2004); distribution of pingos (Ellison 2004; Hutchinson 1989) and distribution of artificial features that may provide access to the chalk, e.g. tunnels, mines, adits, disused water wells, service trenches; zones of higher permeability, e.g. associated with more intense fissuring, or with chalk rock bands (MacDonald and Allen 2001). River terrace deposits and also certain horizons of the Lambeth and Thames Groups can form minor aquifers, of variable permeability and therefore warrant consideration in the context of an IST designed to protect ground and surface water. Understanding of the nature and distribution of the superficial deposits lends itself to the application of hydrogeological domains (Table 1, Lelliott et al. 2006; McMillan et al. 2000).

Table 1: Hydrogeological domains.

\begin{tabular}{|c|c|c|c|}
\hline Group & Domain & & Sub-Domain \\
\hline \multirow{4}{*}{ 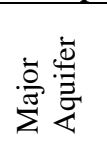 } & \begin{tabular}{l|l}
1 & Outcrop \\
\end{tabular} & $1 \mathrm{a}$ & Chalk at outcrop \\
\hline & & $1 \mathrm{~b}$ & Chalk overlain by $<5 \mathrm{~m}$ low permeability strata \\
\hline & & $1 \mathrm{c}$ & Basal Sand at outcrop \\
\hline & & $1 \mathrm{~d}$ & Basal Sand overlain by $<5 \mathrm{~m}$ low permeability \\
\hline
\end{tabular}




\begin{tabular}{|c|c|c|c|c|}
\hline \multirow[t]{6}{*}{ Group } & \multicolumn{2}{|c|}{ Domain } & & \multirow{2}{*}{\begin{tabular}{|l|} 
Sub-Domain \\
strata \\
\end{tabular}} \\
\hline & & & & \\
\hline & 2 & Permeable superficial deposits & $2 \mathrm{a}$ & $\begin{array}{l}\text { Minor aquifers: Kempton Park Gravel, Taplow } \\
\text { Gravel Formation }\end{array}$ \\
\hline & & & $2 b$ & Alluvium, Alluvium 1 \\
\hline & 3 & $\begin{array}{l}\text { Multiple permeable superficial } \\
\text { deposits including minor aquifer }\end{array}$ & $3 \mathrm{a}$ & $\begin{array}{l}\text { Alluvium, Alluvium 1, Kempton Park Gravel, } \\
\text { Taplow Gravel Formation }\end{array}$ \\
\hline & 4 & $\begin{array}{l}\text { Multiple permeable and } \\
\text { impermeable }(<5 \mathrm{~m} \text { in thickness }) \\
\text { superficial deposits, including minor } \\
\text { aquifer deposits and Lambeth Group } \\
\text { strata }\end{array}$ & $4 \mathrm{a}$ & $\begin{array}{l}\text { Alluvium, Alluvium 1, Kempton Park Gravel, } \\
\text { Taplow Gravel Formation, Peat } 1 \text {, upper mottled } \\
\text { clay, upper shelly clay, lower mottled clay, } \\
\text { lower shelly clay }\end{array}$ \\
\hline \multirow{4}{*}{ 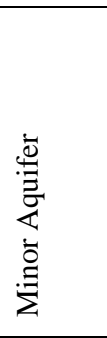 } & \multirow[t]{2}{*}{5} & \multirow[t]{2}{*}{ Outcrop } & $5 \mathrm{a}$ & $\begin{array}{l}\text { Minor aquifer at outcrop (Kempton Park Gravel } \\
\text { Formation, Taplow Gravel Formation, }\end{array}$ \\
\hline & & & $5 b$ & $\begin{array}{l}\text { Minor aquifer overlain by }<5 \mathrm{~m} \text { of low } \\
\text { permeability superficial deposits, e.g. Langley } \\
\text { Silt, }\end{array}$ \\
\hline & 6 & Permeable cover deposits & $6 a$ & $\begin{array}{l}\text { Made Ground, Alluvium, Alluvium 1, Lambeth } \\
\text { Group }\end{array}$ \\
\hline & 7 & Multiple cover deposits & $7 \mathrm{a}$ & $\begin{array}{l}\text { Made Ground, Alluvium, Alluvium 1, Lambeth } \\
\text { Group, Peat }(<5 \mathrm{~m})\end{array}$ \\
\hline \multirow{4}{*}{ 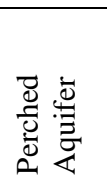 } & \multirow[t]{4}{*}{8} & \multirow[t]{4}{*}{ Perched permeable superficial strata } & $8 \mathrm{a}$ & Alluvium, Alluvium 1, minor aquifer \\
\hline & & & $8 \mathrm{~b}$ & Made Ground \\
\hline & & & $8 \mathrm{~d}$ & Multiple permeable superficial deposits \\
\hline & & & $8 \mathrm{e}$ & $\begin{array}{l}\text { Multiple permeable and impermeable }(<5 \mathrm{~m} \text { in } \\
\text { thickness) superficial deposits }\end{array}$ \\
\hline 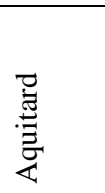 & 9 & Low permeability superficial strata & $9 \mathrm{a}$ & Peat \\
\hline \multirow[b]{2}{*}{ 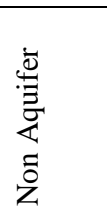 } & \multirow[t]{2}{*}{10} & \multirow[t]{2}{*}{ Non-aquifer bedrock strata } & $\begin{array}{l}10 \\
\mathrm{a}\end{array}$ & London Clay Formation \\
\hline & & & $\begin{array}{l}10 \\
b\end{array}$ & Lambeth Group \\
\hline
\end{tabular}

\section{Contaminated land prioritisation.}

The Environmental Protection Act (1990) is an Act of Parliament of the United Kingdom that defines the structure and authority for waste management and the control of emissions into the environment. The contaminated land regime in the United Kingdom is defined as part of Part IIA of the Environmental Protection Act (1990) and the guidance and regulations that go with it. By placing specific duties on local authorities to inspect their areas to identify contaminated land and remediate it under a "suitable for use" approach it provides a system for the identification and remediation of land where "significant harm is being caused, or there is a significant possibility of such harm being caused, or significant pollution of the water environment is being caused, or there is a significant possibility of such pollution being caused". As a consequence of the placement of responsibility for contaminated land with the Local Authorities there was a growth in the number of site prioritisation tools based on the hazard-pathway-target (receptor) approach, e.g. Ander et al. (2003); Department of the Environment (1995), and Gilman (2003) that was available in the UK. The regulations required Local Authorities to identify and assess potentially contaminated land with a view to the remediation of those sites identified as contaminated. Additionally, ranking of contaminated sites facilitates more efficient 
use of staffing and financial resources by targeting highest priority sites first, in a systematic and defensible way, as enshrined in the statutory guidance for the legislation. The tools that were developed were predominantly qualitative and semiquantitative and were based on similar American and Canadian models, such as those described by Canter et al. (1997). Of these tools, the DRASTIC Index (Aller et al. 1987) has widely informed the development of contaminated land prioritisation tools in the UK, including the British Geological Survey ConSEPT (Contaminated Site Evaluation and Prioritisation Tool), which is an integrated GIS tool developed for the prioritisation of potentially contaminated land (Ander et al. 2003).

With the development of attributed 3-D geological modelling at the BGS (Royse et al. 2009), it was clear that there was an opportunity to take contaminated land prioritisation into the third dimension. This offers the potential for further discrimination of the prioritisation by the incorporation of additional scenarios, such as: aquifers at depth that may be impacted by the construction of deep foundations (basements or piles) causing contaminant re-mobilisation; the influence of the depth of the unsaturated zone and the use of hydrogeological domains (Table 1) that offer further prioritisation discrimination between sites (Lelliott et al. 2006; McMillan et al. 2000).

\section{Earlier approaches to contaminated land prioritisation.}

Under Part IIA, the statutory definition of contaminated land is based on the existence of a pollutant linkage, comprising a contaminant source, a pathway along which the contaminant can move to a receptor or target that may be affected, or potentially affected by the contaminant source. Where a contaminant source is present, but there are no potential effects on a given receptor, the land would not meet the legal definition of "contaminated". Early prioritisation tools were spreadsheet hosted. Subsequent developments have incorporated GIS, as typified by Ground View (the National Environmental Technology Centre) and ConSEPT (a prioritisation tool designed by the BGS).

ConSEPT was developed to assist Local Authorities in the task of implementing Part IIA. The aim was to use readily available data to prioritise potentially contaminated sites on the basis of perceived pollutant linkages. The method adopted by ConSEPT is to establish a pollutant linkage score for three possible pathways: direct contact (or proximity), surface water, and groundwater and four possible receptors: humans, controlled waters, ecology and property. Pollutant linkages can then be rationalised as the combinations of pathways and receptors that are realistically likely to occur. Seven plausible pollutant linkage types can be identified by ConSEPT (Figure 3). 

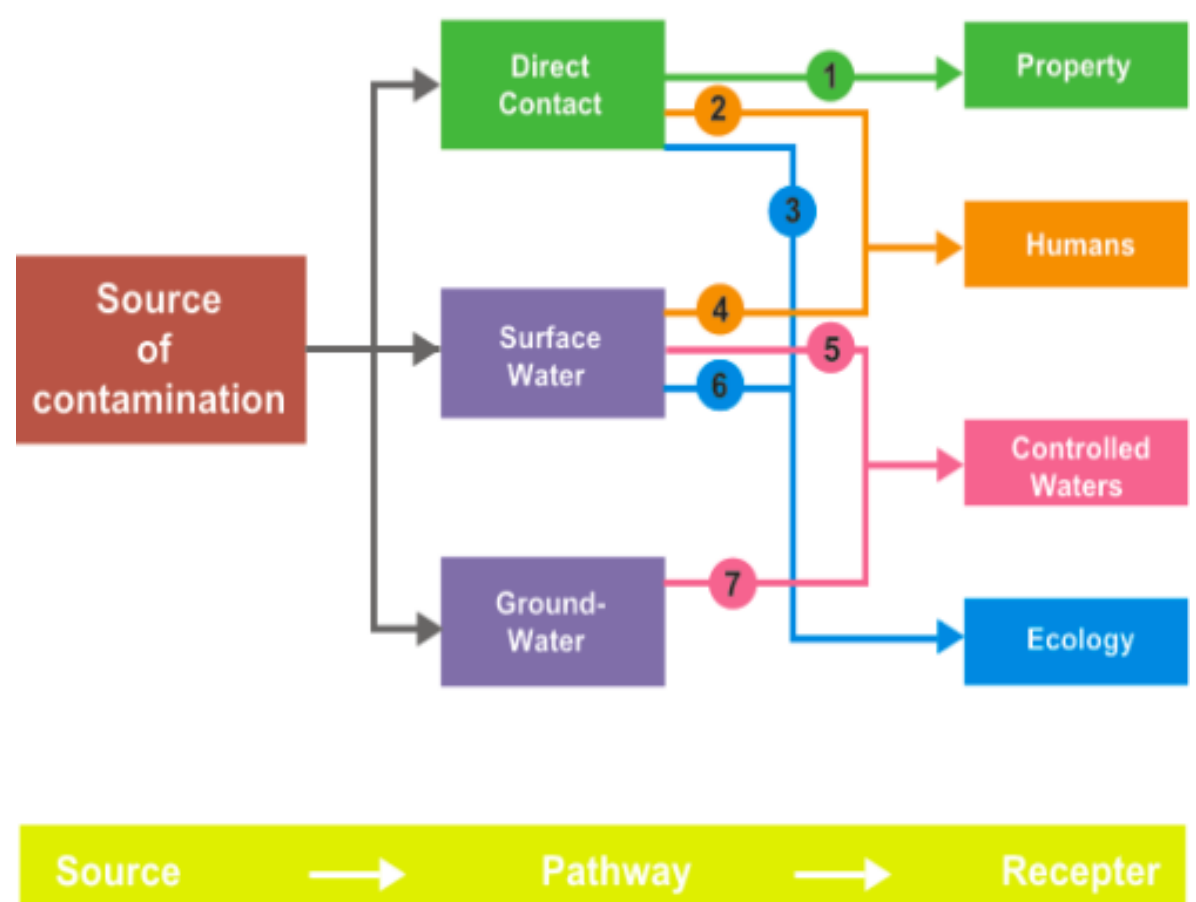

Figure 3: ConSEPT pollutant linkages

The individual source, pathway and receptor scores are derived from a set of evaluation factors, which are processed by a GIS using a combination of two types of automated query:

1. Spatial queries, e.g. occurrence of residential housing within a specified buffer zone

2. Attribute queries, e.g. the permeability of the surface geology at the source site Buffer zones are used to perform spatial queries (Figure 4). 


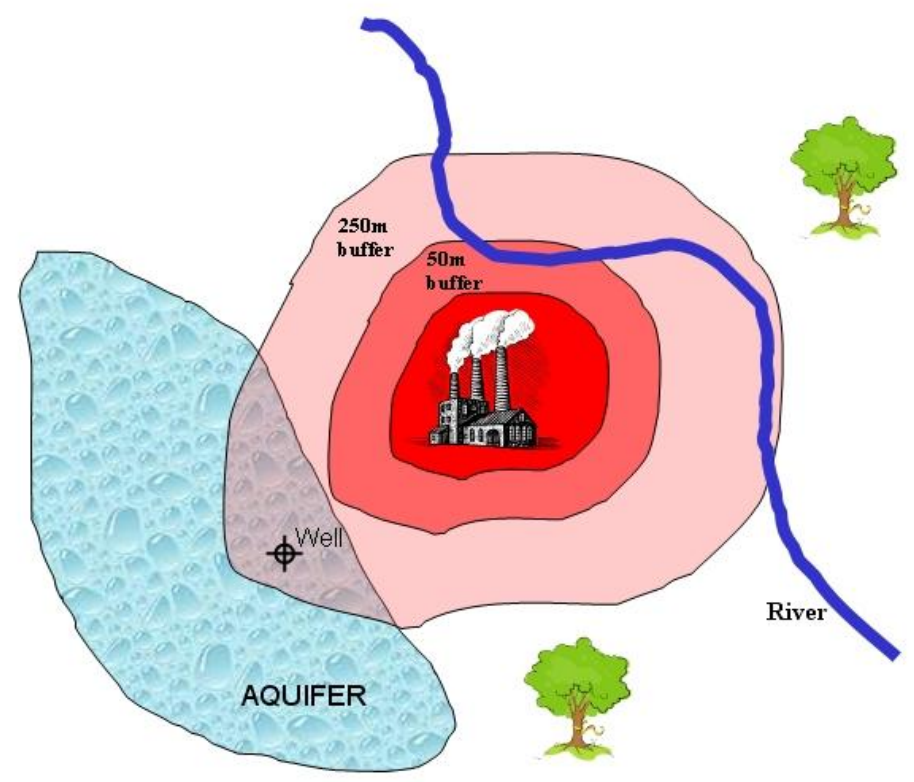

Figure 4: Use of Buffer Zones in ConSEPT: example of a search of rivers, wells and aquifers within 50 and $250 \mathrm{~m}$ of the source site

Applying evaluation factors results in numerical scores being generated for each of the source, pathway and receptor components. These numerical scores are converted to classes ranging from ' $A$ ' to ' $E$ ' where ' $A$ ' represents the highest possible score and ' $E$ ' the lowest possible score. For instance the source component has a maximum score of 33 and is classified as follows:

- A: scores from 26 to 33

- B: scores from 20 to 26

- $\mathrm{C}$ : scores from 14 to $20 \quad \uparrow$ increasing susceptibility

- D: scores from 7 to 14

- E: scores from 0 to 7

The conversion to classes prevents the user from placing unwarranted precision on the numerical scores. The overall pollutant linkage score is taken to be the lowest ranking class from the source, pathway and receptor components. For example, consider the following example:

- Source score: A

- Direct Contact Pathway score: C

- Human Receptor score: A

The score for this pollutant linkage would be $\mathrm{C}$, taken from the lowest scoring component (the pathway). Consequently (as required by legislation), for a site to be considered contaminated it must generate significant scores for each of the three components.

Applications of ConSEPT have been developed for a number of Local Authorities across the UK, providing a valuable tool for performing a first sift of potentially 
contaminated sites, with a view to identifying the sites that require more detailed site investigation. There are however a number of limitations of the ConSEPT model, as summarised in Table 2.

\section{Table 2: Limitations of the ConSEPT model}

\begin{tabular}{|l|l|}
\hline Limitation & Description \\
buffers. & $\begin{array}{l}\text { The use of circular buffers can generate false pollutant } \\
\text { linkages. Taking the example of Figure 4, the ConSEPT } \\
\text { pathway scoring process will identify a river that falls within } \\
\text { the 50m buffer. Additionally, during the receptor scoring, an } \\
\text { aquifer is identified within the 250m buffer and therefore } \\
\text { ConSEPT reports a possible pollutant linkage as the river } \\
\text { providing a pathway to the aquifer. However the river and } \\
\text { aquifer are some distance from each other and never } \\
\text { intersect. Thus in reality the pathway and receptor are not } \\
\text { linked and do not form a pollutant linkage. }\end{array}$ \\
\hline $\begin{array}{l}\text { No account taken of } \\
\text { directions of flow and } \\
\text { slope. }\end{array}$ & $\begin{array}{l}\text { In ConSEPT, because no account is taken of the direction of } \\
\text { flow, a river will be identified as a pathway irrespective of } \\
\text { whether it flows to or from a potential receptor. Additionally, } \\
\text { although slope is used as an evaluation factor, the scoring } \\
\text { does not take into account whether the slope is towards or } \\
\text { away from a potential receptor. }\end{array}$ \\
\hline $\begin{array}{l}\text { No account taken of } \\
\text { multiple pollutant } \\
\text { linkages }\end{array}$ & $\begin{array}{l}\text { When analysing the pollutant linkages for a source site and } \\
\text { determining an overall score, ConSEPT generates a score for } \\
\text { each of the seven linkage types shown in Figure 3, based on } \\
\text { how likely that type of linkage is to exist. It does not take } \\
\text { into account the number of individual linkages that may be } \\
\text { present. This is due to the fact that by using the circular } \\
\text { buffer search method ConSEPT can only identify the } \\
\text { potential for linkages to occur, it cannot trace individual } \\
\text { linkages through source to pathway to receptor. As a result a } \\
\text { site that in reality has one significant pollutant linkage will } \\
\text { score notably higher than a site with several moderately } \\
\text { scoring linkages. }\end{array}$ \\
\hline No use of 3-D data & $\begin{array}{l}\text { All data used in ConSEPT are 2-D, and where geology data } \\
\text { is queried, only the properties of surface formations are taken } \\
\text { into account. This imposes a severe limitation to the scoring } \\
\text { of groundwater pathways in particular. }\end{array}$ \\
\hline
\end{tabular}

\section{The Initial Screening Tool (IST).}

As a result of stakeholder analysis the decision was made to develop the Initial Screening Tool (IST), with a focus on addressing the limitations identified in the ConSEPT methodology (Table 2) and directing the tool at groundwater and surface water protection. The purpose of the IST is to rank sites that are being considered for a scheduled future development, based on the identification and scoring of potential 
pollutant linkages resulting from contaminants mobilised by the proposed redevelopment. The implementation of the IST was progressed in three stages:

1. Following a literature review of screening tools for assessing the risk to groundwater and surface water from contaminants mobilised by redevelopment, a list of potential relevant factors were identified and analysed to determine whether and how these factors could be integrated in the IST.

2. Initial source, pathway and receptor rules (known as evaluation factors) were drafted and the datasets required to implement them were sourced.

3. The evaluation factors and datasets were incorporated in a GIS and the scoring methodology was refined iteratively.

\section{IST Scoring Methodology.}

By including more detailed, 3-D geological, surface water and groundwater datasets the goal of the IST was to indentify and model individual pollutant linkages. By focussing on groundwater and surface water, the model examines four categories of pollutant linkage, as shown in Figure 5.
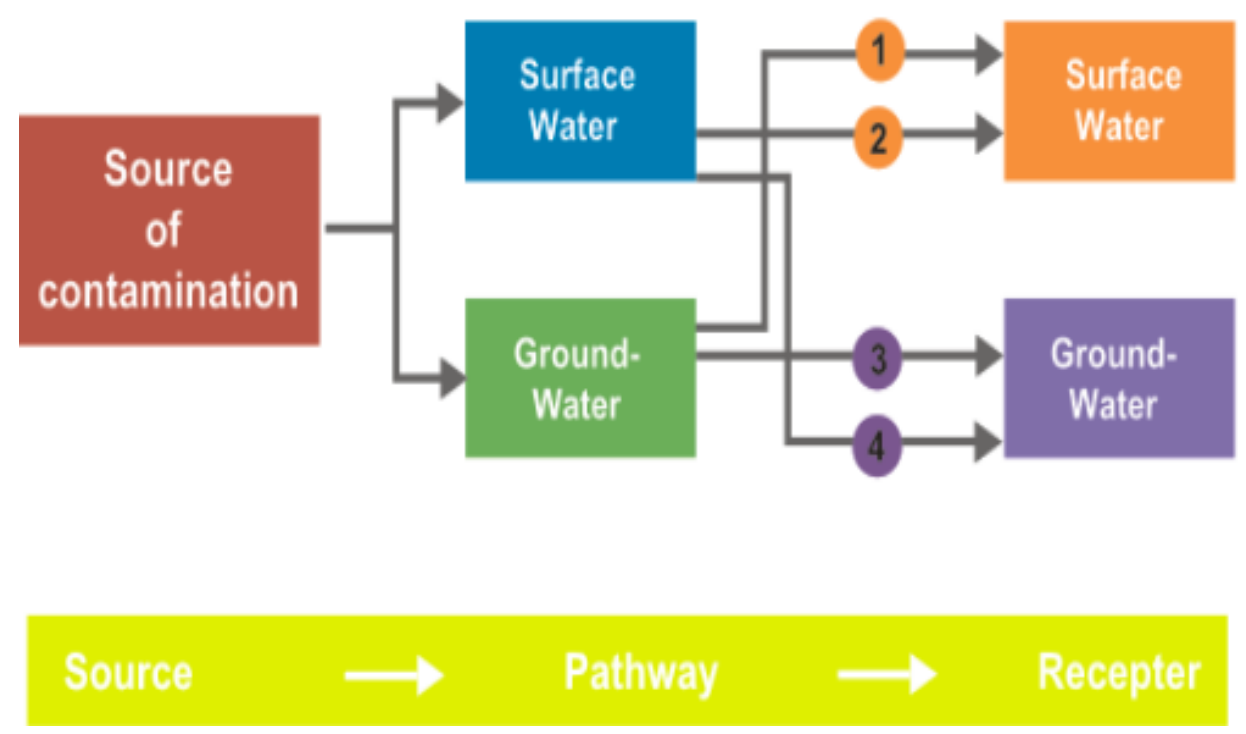

Figure 5: IST pollutant linkages

The source scoring evaluation factors are similar to those used by ConSEPT. Contaminant potential is derived using DEFRA (Table 2.3, Department for Environment Food and Rural Affairs and Environment Agency 2002 b), which lists the contaminants most likely to be found 'in quantities which may be harmful' for given generically classified industries. The score is derived by taking the total number of priority contaminants associated with a potentially contaminative land use, i.e. each contaminant scores ' 1 '. This results in a possible maximum score of 39: 21 inorganic substances/parameters; 14 organic substance groups, and 4 priority contaminants that are not included in CLR 8 (DEFRA 2002b), namely ammonium, organo-metallics, carbon dioxide and methane. For the sake of simplicity and score traceability, no weighting (e.g. based on toxicity, mobility and bioavailability) has been placed on the priority contaminants. Weighting would have required extensive supporting research and would have added to the complexity of the system with a potential requirement for site-specific data to function effectively. Additionally, the source evaluation 
factors include the area of the site, based on the assumption that the larger the area covered by a potentially contaminating activity the greater the scale of the operation, consequently the greater the potential contaminant mass and the greater the potential for harm if receptors are present.

The IST surface water pathway evaluation factors (Table 4) consist of: proximity, flood potential and topography. Proximity is based on the shortest distance between the source site and a surface water pathway feature. Flooding was considered because it provides a potential agent for the remobilisation and transport of contaminants from a site to a receptor. This evaluation factor does not quantitatively assess the effect of transport, but highlights that it could take place. The highest scoring Environment Agency flood potential area to intercept the source feature is used to generate the score. Topography scores are based on the magnitude of the slope towards a receptor. The average gradient of the surface water pathway is used to generate this score.

Developments in the IST groundwater pathway evaluation factors were focused on achieving greater alignment with the methodology used in the derivation of the Environment Agency P20 risk assessment (Marsland et al. 1999). Hydraulic gradient impacts the transmission of contaminants, and is calculated from the slope of the water table in the direction of flow. Based on the hypothesis that if a source site is sealed against infiltration there will be no potential for contaminant mobilisation the presence or absence of surface sealing was incorporated as an evaluation factor. Similarly, provision has been made for the presence of impermeable strata beneath the source, which would also serve to protect groundwater. This has been integrated by provision for the incorporation of hydrogeological domains (Table 1). Also integrated within the hydrogeological domain concept is the recognition of varying thicknesses of low permeability strata within the unsaturated zone (Waters et al. 2006). Reflecting the focus on aquifer protection, the impact of the ConSEPT evaluation factor for preferential pathways (high permeability features) was given a higher ranking in the IST. Another evaluation factor to be incorporated is the overall thickness of the unsaturated zone, which influences the potential for retardation and dispersion of a given contaminant plume. It follows that the thicker the unsaturated zone the greater the potential to minimise the impact on groundwater aquifers. The addition of an evaluation factor that reflects planning for proposed foundation construction on a given site was one of the key aims in the development of the IST. This evaluation factor takes account of the proposed foundation depth (deeper foundations are assumed to have the potential to mobilise contamination to greater depth and provide connection between otherwise isolated aquifers) and to foundation type. The latter is considered important particularly in the context of piling, for instance large displacement piles are considered more likely to transfer contaminants to greater depth than non-displacement, or bored auger piles and the Environment Agency (Environment Agency 2001) recommends that where possible raft foundations should be used instead of piles on contaminated sites underlain by aquifers.

As one of the key objectives of the IST was the provision of ranking based on the contaminating potential to groundwater and surface waters, it was considered that the range of groundwater and surface water receptor evaluation factors should be extended to reflect this. Accordingly, in addition to proximity, the IST surface water evaluation factors now include a classification of the surface water receptor based on: Large River (greater than 33m wide), Small River (10-33m wide), Large Stream (3- 
10m wide), Small Stream (less than $3 \mathrm{~m}$ wide), Wetlands, Docks, Pond, Land Drain and Ditch. This classification was developed following consultation with hydrogeological colleagues and is based on UK hydrological experience. The IST groundwater receptor evaluation factors include proximity, the classification of principal aquifers and secondary aquifers, as well as the identification of Environment Agency listed Water Abstraction Sites and Source Protection Zones (SPZ's).

Tables 3 to 7 summarise the evaluation factors, implemented by the IST. These factors are divided into: Source, Surface Water Pathway, Groundwater Pathway, Surface Water Receptor and Groundwater Receptor.

Table 3: IST Source Evaluation Factors.

\begin{tabular}{|l|l|}
\hline \multicolumn{1}{|c|}{ Evaluation Factor } & \multicolumn{1}{c|}{ Description } \\
\hline Contaminant potential & $\begin{array}{l}\text { A ranking based on the contaminants most likely to } \\
\text { be found 'in quantities which may be harmful' for } \\
\text { given generically classified industries. }\end{array}$ \\
\hline Size of site & $\begin{array}{l}\text { The larger the size of site, the greater the scale of the } \\
\text { operation, the greater the potential contaminant mass } \\
\text { and the greater the potential for harm if receptors are } \\
\text { present. }\end{array}$ \\
\hline
\end{tabular}

Table 4: IST Surface Water Pathway Evaluation Factors.

\begin{tabular}{|l|l|}
\hline \multicolumn{1}{|c|}{ Evaluation Factor } & \multicolumn{1}{|c|}{ Description } \\
\hline Proximity & $\begin{array}{l}\text { Shortest distance from source site to surface water } \\
\text { feature. }\end{array}$ \\
\hline Flood potential & $\begin{array}{l}\text { Flooding provides a potential agent for the transport } \\
\text { of contaminants from a site to a receptor. The } \\
\text { pathway evaluation factor is derived from three } \\
\text { categories: no flood potential, low to medium risk of } \\
\text { flooding (with an annual probability of flooding of } \\
0.1-1.0 \% \text { from rivers and } 0.1-0.5 \% \text { from the sea), or } \\
\text { high risk of flooding (with an annual probability of } \\
\text { flooding of 1.0\% or greater from rivers and } 0.5 \% \text { or } \\
\text { greater from the sea). This information is supplied by } \\
\text { the Environment Agency. }\end{array}$ \\
\hline Topography & $\begin{array}{l}\text { The mean magnitude of the gradient of the surface } \\
\text { water pathway along its course towards a receptor. }\end{array}$ \\
\hline
\end{tabular}

Table 5: IST Groundwater Pathway Evaluation Factors.

\begin{tabular}{|l|l|}
\hline \multicolumn{1}{|c|}{ Evaluation Factor } & \multicolumn{1}{c|}{ Description } \\
\hline Proximity & Distance from source site to groundwater pathway. \\
\hline Vulnerability & $\begin{array}{l}\text { Model specific hydrogeological domains (e.g. Lelliott } \\
\text { et al. 2006). }\end{array}$ \\
\hline Surface sealing & $\begin{array}{l}\text { An assessment of whether or not the artificial surface } \\
\text { of the site prohibits contaminant migration towards } \\
\text { the aquifer. }\end{array}$ \\
\hline Potentially high permeability & The possibility that natural or artificial structures \\
\hline
\end{tabular}




\begin{tabular}{|l|l|}
\hline features & $\begin{array}{l}\text { passing through any soil, or sediments, forming an } \\
\text { unsaturated zone may result in preferential (rapid) } \\
\text { flow of contaminants into the aquifer. For example } \\
\text { Boreholes, Water Wells and Faults. }\end{array}$ \\
\hline Low permeability interfaces & $\begin{array}{l}\text { The presence of low permeability interfaces in the } \\
\text { solid geology in the unsaturated zone, e.g. clay beds } \\
\text { in the Lambeth Group can be particularly important in } \\
\text { the unsaturated zone both in retaining and retarding } \\
\text { contaminant migration. This is derived from the } \\
\text { lithological descriptors in the 3-D geological model. }\end{array}$ \\
\hline Hydraulic gradient & $\begin{array}{l}\text { The slope of the water table in the direction of flow, } \\
\text { which influences the rate and direction of } \\
\text { contaminant migration. This data is derived from } \\
\text { groundwater level data. }\end{array}$ \\
\hline Unsaturated zone thickness & $\begin{array}{l}\text { Derived from the groundwater level subtracted from } \\
\text { the digital terrain model, the unsaturated zone } \\
\text { thickness influences the potential for retardation and } \\
\text { dispersion of a given contaminant plume. }\end{array}$ \\
\hline Proposed foundations & $\begin{array}{l}\text { A factor that reflects the potential for the proposed } \\
\text { foundation to provide preferential contaminant } \\
\text { pathways, which is based on the proposed foundation } \\
\text { type and depth. }\end{array}$ \\
\hline
\end{tabular}

Table 6: IST Surface Water Receptor Evaluation Factors.

\begin{tabular}{|l|l|}
\hline \multicolumn{1}{|c|}{ Evaluation Factor } & \multicolumn{1}{c|}{ Description } \\
\hline Proximity & Distance of surface water from source site. \\
\hline Surface water classification & $\begin{array}{l}\text { Classification of receptor e.g. large river, small river, } \\
\text { stream, pond etc. }\end{array}$ \\
\hline
\end{tabular}

Table 7: IST Groundwater Receptor Evaluation Factors

\begin{tabular}{|l|l|}
\hline \multicolumn{1}{|c|}{ Evaluation Factor } & \multicolumn{1}{c|}{ Description } \\
\hline Proximity & Distance of aquifer from the source. \\
\hline Aquifer classification & Principal or secondary aquifer. \\
\hline $\begin{array}{l}\text { Groundwater receptor } \\
\text { classification }\end{array}$ & $\begin{array}{l}\text { Environment Agency Water Abstraction points and } \\
\text { Source Protection Zones. }\end{array}$ \\
\hline
\end{tabular}

Scoring the IST evaluation factors.

The evaluation factors are scored through a combination of spatial and attribute queries utilising an approach that is comparable with ConSEPT. The main enhancement lies in the complexity of the spatial queries, which allow the identification of individual pollutant linkages. Scoring is automated through a customised GIS application. An overview of the scoring algorithm is given below:

Scoring starts with a source site, typically between 0.01 and 20 hectares in plan area, selected by the user. Source sites are categorised by land-use, based on the classified industries listed by DEFRA (Table 2.3, Department for Environment Food and Rural 
Affairs and Environment Agency 2002b). This list is a summary of the DoE 'industry profile' series and was specifically developed to assist with the classification of potentially contaminated land in the UK. Typical industries from this list include:

- Chemical Works: Organic Chemicals Manufacturing Works

- Dry Cleaners

- Gasworks, Coke Works and other Coal Carbonisation Plants

- Road Vehicle Servicing \& Repair Works, Garages \& Filling Stations, Transport and Haulage Centres

A source zone of influence (source ZoI) is created around the source site. This comprises a cone (ÓDochartaigh, et al. 2009) generated in accordance with:

An inner arc radius of the source $\mathrm{ZoI}\left(\mathrm{R}_{\mathrm{I}}\right)$ :

$$
\mathrm{R}_{\mathrm{I}}=\sqrt{\frac{A}{\pi}} \text { (where } \mathrm{A} \text { is the area of the Source site) }
$$

An Outer arc radius of the source ZoI $\left(\mathrm{R}_{\mathrm{O}}\right)$ :

$$
\mathrm{R}_{\mathrm{O}}=4 \mathrm{R}_{\mathrm{I}}
$$

The Direction of source ZoI is down gradient, as calculated from the Digital Terrain Model.

If the source ZoI does not intersect with either a surface water or aquifer feature, 'no pollutant linkage' is reported for the chosen source site and the scoring concludes. However if there is an intersection, connectivity has been identified between source and pathway and the scoring algorithm proceeds, attempting to identify individual pollutant linkages. The four possible linkage types and the conditions in which each is said to potentially exist are considered below:

\section{1) Source -> Surface Water pathway -> Surface Water receptor}

The source ZoI intersects with a surface water feature. In this situation, the surface water acts as both pathway and receptor.

2) Source -> Surface Water pathway -> Groundwater receptor

The source ZoI intersects with a surface water feature, which is followed downstream for a specified distance to generate a surface water pathway ZoI. The length of the surface water pathway ZoI is based on the size of the surface water feature (small stream $10 \mathrm{~m}$, small river: $150 \mathrm{~m}$ and large river: $1000 \mathrm{~m}$ ). The surface water pathway $\mathrm{ZoI}$ intersects an aquifer feature resulting in connectivity to a groundwater receptor. To identify the portion of the aquifer potentially affected, a groundwater receptor $\mathrm{ZoI}$ is created. The groundwater receptor $\mathrm{ZoI}$ is a cone generated using the same formulae as the source ZoI cone (Equations (1) and (2)), but where ' $A$ ' is the area of the intersection between surface water pathway ZoI and the aquifer, and the direction of the cone is down hydraulic gradient. 


\section{3) Source -> Groundwater pathway -> Groundwater receptor}

The source ZoI intersects with an aquifer feature. In this situation, the aquifer acts as both pathway and receptor. To identify the portion of the aquifer potentially affected, a groundwater pathway $\mathrm{ZoI}$ is created. The groundwater pathway $\mathrm{ZoI}$ is a cone generated using Equations (1) and (2), but where ' $A$ ' is the area of the intersection between the Source $\mathrm{ZoI}$ and the aquifer, and the direction of the cone is down hydraulic gradient.

\section{4) Source -> Groundwater pathway -> Surface Water receptor}

The source ZoI intersects with an aquifer feature resulting in connectivity to a groundwater pathway. To identify the portion of the aquifer potentially affected, a groundwater pathway ZoI is created. The groundwater pathway ZoI is a cone generated using Equations (1) and (2), but where ' $A$ ' is the area of the intersection between the source ZoI and the aquifer, and the direction of the cone is down hydraulic gradient. The groundwater pathway ZoI intersects with a surface water feature resulting in connectivity to a surface water receptor.

A Pollutant Linkage Register is maintained of all pollutant linkages identified. Any number of pollutant linkages may be identified as, for example, the source ZoI may intersect several surface water features each of which will be followed downstream to possible receptors. Each pollutant linkage in the Pollutant Linkage Register is scored, by applying the relevant evaluation factors to each of the three components (source, pathway and receptor). The overall pollutant linkage score is derived from the lowest of the three component scores. This aligns with the philosophy that for a pollutant linkage to exist, all three of the components must exist and be significant. Finally each individual pollutant linkage score is summed to give a final score for the chosen site.

To illustrate the scoring, Figure 6 shows an example of how a 'Source -> Surface Water pathway -> Groundwater receptor' pollutant linkage is modelled by the IST: 


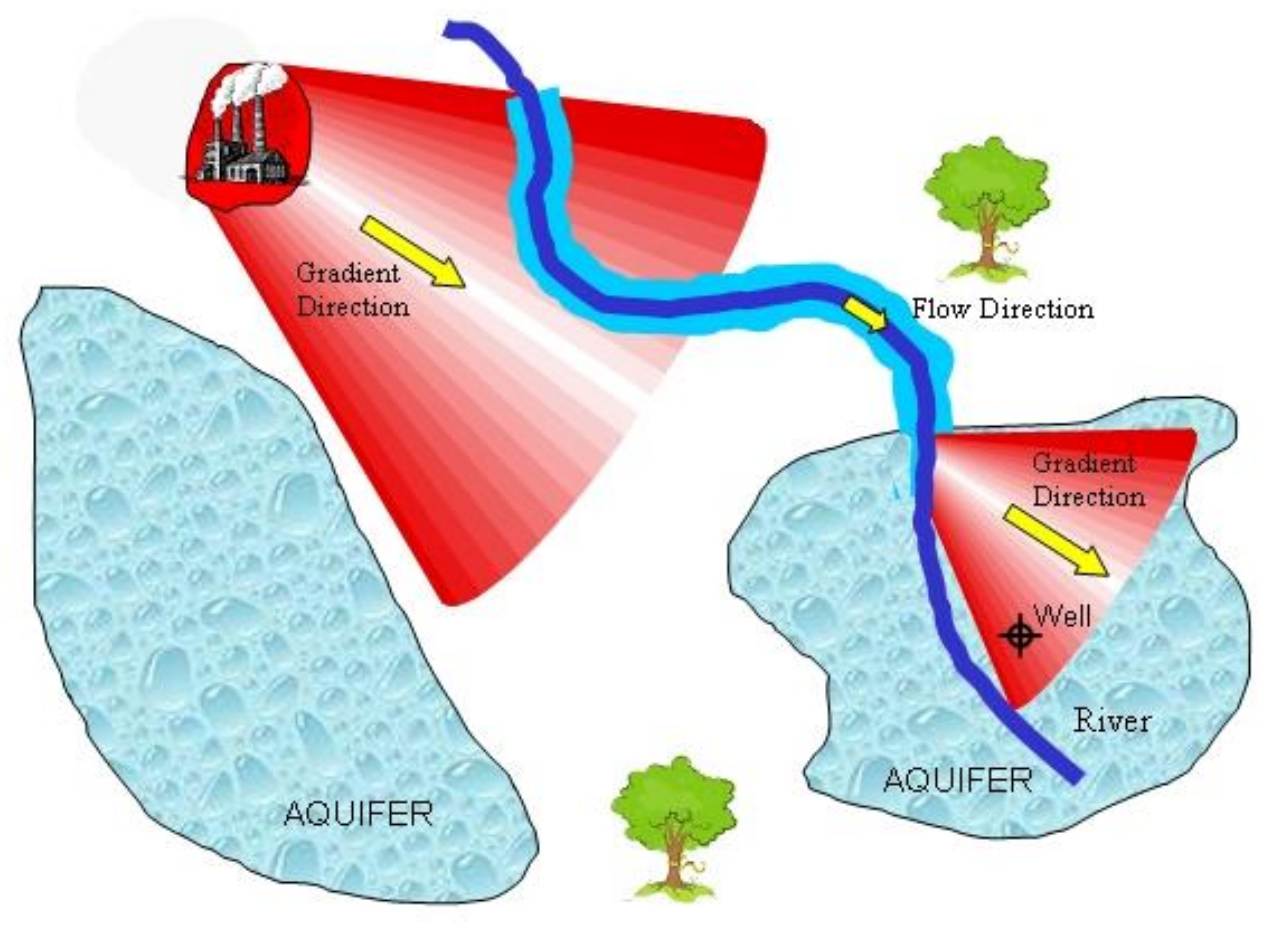

Figure 6: Modelling Pollutant Linkages in the IST

The source site in the example (Figure 6) potentially impacts on a surface water pathway, which in turn provides a linkage to a groundwater receptor. The scoring starts by creating a source ZoI. This ZoI comprises a cone in the direction of the surface gradient, with a size relative to the area of the source site. The source ZoI intersects with a river resulting in the identification of a potential pathway. The effects of the pathway on contaminant migration are modelled by following the river downstream for a specified distance (which is relative to the size of the river), thus generating a surface water pathway ZoI. Within this surface water pathway ZoI, the river can be seen to intersect with an aquifer. At the area of intersection a groundwater receptor ZoI is created, comprising a cone in the direction of the hydraulic gradient, with a size relative to the extent of the intersection of river and aquifer. This pollutant linkage is added to the Pollutant Linkage Register and scored using the relevant evaluation factors.

\section{GIS Implementation}

GIS based applications lend themselves to site ranking, because of the ability to overlay and query the numerous related spatial datasets that contribute to site evaluation. This is particularly true of the IST, which comprises a novel prioritisation tool in that it applies GIS rules in three dimensions and adopts a cone shaped search area (ÓDochartaigh et al. 2009). The IST GIS was implemented in ESRI's ArcGIS, with customisation provided through the Visual Basic for Applications (VBA) programming language. In order to carry out modelling of individual pollutant linkages for the IST it was necessary to employ a number of advanced GIS techniques, some of which are summarised below. 
Modelling the possible contaminant migration along a river was implemented through the use of a Network dataset. By building the rivers into a network, such that each link in the network can only be traversed in one direction, it is possible to apply network analysis techniques, similar to those commonly used to provide directions and travel times from a road network. As a result, given a starting point, network analysis allows the calculation of the portion of the river network that can be reached by contaminants travelling a specified distance. Creating circular search buffers in a GIS is a trivial task, however creating Zone of Influence cones in a given direction and modelling the interaction with potential pathway and receptor features is less straightforward and necessitates use of the geoprocessing capabilities of ArcGIS. Determining the average slope direction of the terrain and water level models requires the use of statistical geoprocessing techniques whilst modelling the interaction between source, pathway and receptor features requires the use of intersection geoprocessing functionality. The IST evaluation factors were implemented as a number of rules executed within the GIS. Each of the rules is stored in a database table, allowing users to view and edit rules as required. Output from the IST risk ranking tool is directed to a Microsoft WORD report, which includes maps showing the source, pathway and receptor ZoI's, as well of documentation of each pollutant linkage identified, including details of the score achieved by each evaluation factor. Figure 7 shows a screenshot from the GIS alongside a page from the output report. This page shows the selected source site and its associated source ZoI (Red), a surface water pathway (Blue) and a receptor ZoI (Green).

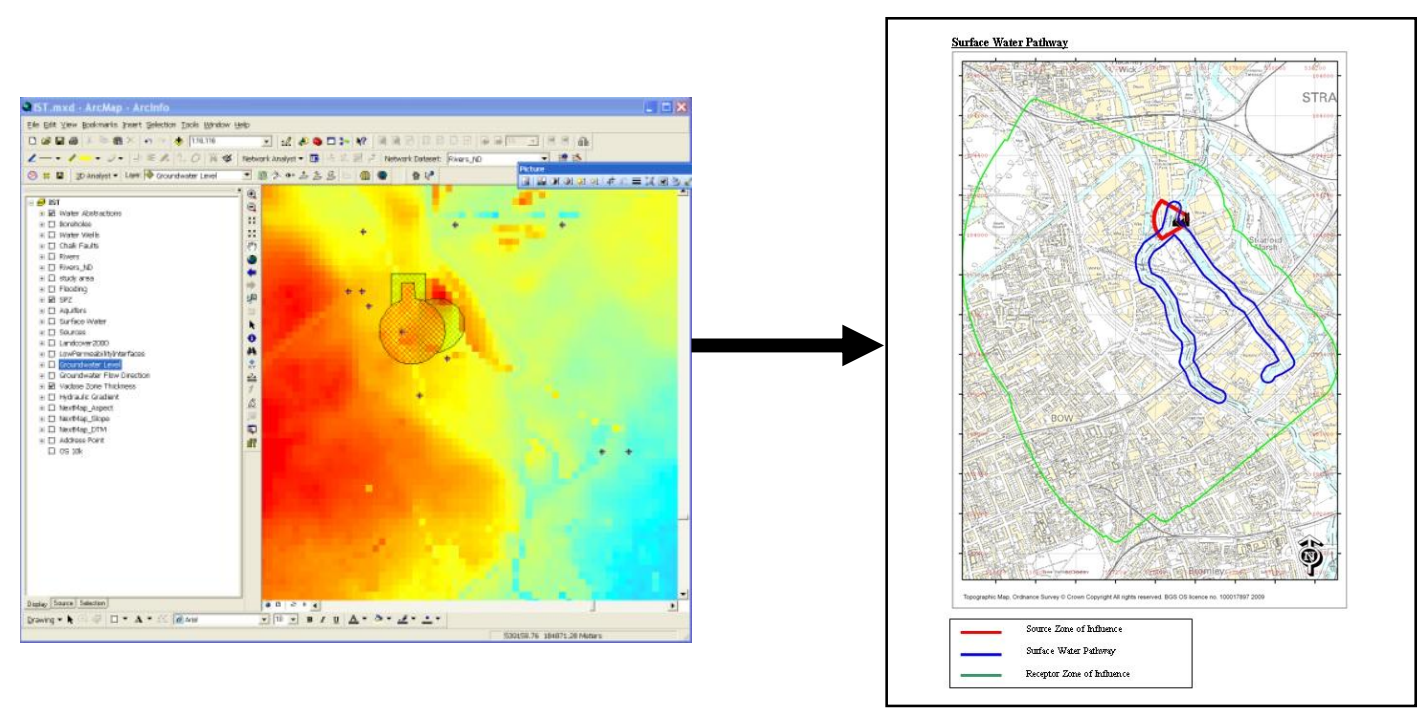

OS Data @ Crown Copyright. All rights reserved. BGS 100017897/2010

Figure 7: IST report extract.

One of the key, and unforeseen, challenges in implementing the IST was managing the communication between scientists and GIS staff. Due to the increased complexity of the surface water and groundwater pathway evaluation factors, several iterations were required before the implemented rules matched the scientists' vision.

\section{Evaluation and Discussion.}


The IST comprises a GIS application designed to support decision-making with respect to the protection of groundwater and surface water. This is achieved through the interrogation of hydrogeologically attributed 3-D geological models and GIS data layers. The implementation of the application, demonstrates its worth as a planning tool for ranking sites that are being considered for future development (Figure 7). Focusing on the impact to groundwater and surface water, the tool identifies and scores potential pollutant linkages resulting from contaminants mobilised by proposed redevelopment. This can be seen in the example highlighted by Figure 7, where the source ZoI intersects with the River Lea, potentially transporting contaminants downstream above an aquifer, resulting in a substantial groundwater receptor ZoI in the direction of the hydraulic gradient (south west). In turn the groundwater receptor ZoI intersects with a Source Protection Zone, thus indentifying a potentially significant pollutant linkage from the source site to a Source Protection Zone, which once scored using the evaluation factors achieves a score of ' $\mathrm{B}$ ' (the second highest class on the scale 'A' highest to ' $E$ ' lowest).

The IST was, in part, designed to address the limitations of ConSEPT (Table 2). The enhancements provided by the IST are detailed in Table 8 .

Table 8: IST methodologies used to overcome the limitations of ConSEPT.

\begin{tabular}{|c|c|}
\hline Limitation & Implementation in IST \\
\hline $\begin{array}{l}\text { Use of circular } \\
\text { buffers }\end{array}$ & $\begin{array}{l}\text { Instead of circular search buffers, the IST generates cone shaped } \\
\text { search areas which vary in size and direction based on the } \\
\text { relevant source, pathway or receptor feature. For example a cone } \\
\text { for detecting receptors via a groundwater pathway will be angled } \\
\text { in the direction of groundwater flow. By searching for pathways } \\
\text { and receptors in a given direction it becomes possible to identify } \\
\text { and trace individual pollutant linkages. This provides a significant } \\
\text { improvement over a circular buffer search which does not } \\
\text { identify whether sources, pathways and receptors interact, only } \\
\text { that they were all located within a specified distance of the } \\
\text { source. }\end{array}$ \\
\hline $\begin{array}{l}\text { No account taken } \\
\text { of directions of } \\
\text { flow and slope }\end{array}$ & $\begin{array}{l}\text { All surface water features held in the IST are allocated a flow } \\
\text { direction, so that potential contaminant migration is only } \\
\text { modelled in the direction of flow. Similarly groundwater flow } \\
\text { direction is derived from a water table elevation model allowing } \\
\text { potential contaminant migration to be modelled in this direction } \\
\text { only. In addition, as part of the source ZoI generation, an aspect } \\
\text { dataset derived from the DTM, allows the direction of potential } \\
\text { contaminant migration from the source site to be identified. }\end{array}$ \\
\hline $\begin{array}{l}\text { No account taken } \\
\text { of multiple } \\
\text { pollutant linkages }\end{array}$ & $\begin{array}{l}\text { As a result of modelling individual pollutant linkages it becomes } \\
\text { possible to include in the final site ranking a measure of how } \\
\text { many potential pollutant linkages have been identified. This } \\
\text { provides a significant improvement, in that sites with a number of } \\
\text { moderately scoring linkages will register, along with those with a } \\
\text { single high scoring linkage. }\end{array}$ \\
\hline $\begin{array}{l}\text { No use of 3-D } \\
\text { data }\end{array}$ & $\begin{array}{l}\text { BGS has generated a 3-D geological and hydrogeological model } \\
\text { of the Thames Gateway region (Royse et al. 2009). Surfaces can }\end{array}$ \\
\hline
\end{tabular}




\begin{tabular}{|c|c|}
\hline & $\begin{array}{l}\text { be extracted at any depth allowing much greater analysis of } \\
\text { underlying geology than possible using the ConSEPT method of } \\
\text { analysing surface geology only. 3-D data has been used to } \\
\text { generate the following layers which are key to the groundwater } \\
\text { pathway evaluation factors: low permeability interfaces, depth to } \\
\text { water table, hydraulic gradient and unsaturated zone thickness. }\end{array}$ \\
\hline
\end{tabular}

A number of difficulties were encountered at the design stage. Some of the datasets used in the development of the IST were difficult to obtain and could be equally or more difficult to obtain in other regions. In particular, determining the depth of the unsaturated zone/level of the water table in the area of the Olympic Park was problematic. This was not surprising, as many groundwater levels that are obtained from boreholes represent the head associated with confined aquifers and whilst this is also likely to prove difficult in other areas, it is increasingly being addressed to meet the demands of groundwater modellers. Additionally ascribing a surface water pathway range associated with surface water courses (i.e. the distance contaminants will potentially be transported downstream) was found to be problematic.

Consideration was given to the P20 approach to assessments carried out to determine remediation target concentrations (Marsland et al. 2003). This methodology uses Kd (soil/water partition coefficient) values to assess the potential for contaminant partitioning between the soil and pore water. Although Kd values are not generally available and they are broadly reflected in the fraction of organic carbon (foc) for each lithology. Following discussion and evaluation of existing datasets it was decided that there was insufficient data availability to incorporate an foc evaluation factor at this stage.

Whilst the Olympic Park site was a good choice for the pilot study from the perspective of there being a known range of potential contaminative sources and the good availability of detailed digital 3-D geology data, there were also some limitations with this site. The area comprises a single river system (River Lea), underlain by a single chalk aquifer, which limits the opportunity to demonstrate the full potential of the IST to identify multiple pollutant linkages. More specifically, as the area is underlain by a single aquifer, all source sites have a single potential groundwater pathway and receptor. An additional problem is that the quality of water level data for the area was relatively poor, which impacts on the quality of the results produced in this study area. Whilst the IST integrates the 3-D data through interrogation, it is not a completely integral 3-D model. The zones of influence generated by the model are generated in 2-D. Thus a scenario could exist in more varied topographies, with interbedded strata, where a groundwater aquifer dips beneath a surface water course without hydraulic connectivity, but the current version of the model would assume connection. This will be a focus for future development of the IST.

\section{Conclusions.}

The IST has achieved its goal of developing a methodology, based on detailed 3-D geological and hydrogeological data, to assist the planning environment in the 
assessment of the potential risk to groundwater and surface waters from contaminants mobilised by redevelopment. It provides significant improvements to the identification of pollutant linkages over previous GIS based scoring systems. The combination of detailed 3-D data, identification of individual pathways and improved scoring of evaluation factors has clear benefits in assisting the planning community in the assessment of the potential risk of contaminant mobilisation to groundwater and surface waters. It is recognised that there are limitations on how widely the techniques implemented by the IST can be applied, based primarily on the availability of detailed digital 3-D geological and hydrological data. This data is available for the Thames Gateway region and some other urban areas, but not at a national scale.

A key development for the future, to more accurately model pollutant linkages, will be the generation of groundwater zones of influence in 3-D. A number of other future developments should be explored, including making region or site specific changes to evaluation factors. For example, consideration should be given to generating an additional evaluation factor to take account of the potential for contaminant mobilisation as a result of the groundwater draw-down that will be required to construct proposed foundations. A further improvement would be the addition of a groundwater evaluation factor to represent the permeability of the receiving aquifer. The incorporation of a foc evaluation factor would align the methodology more closely with numerical approaches to determining remediation values (Marsland et al. 2003). Additionally more analysis of the effect of mobilised contaminants on human receptors could be addressed leading to the identification of remediation requirements.

The use of the hydrogeological domain approach (Table 1) provides a neat way of integrating hydrogeological properties with the understanding of facies/ lithological distribution in the 3-D geological models that underpin the IST. Anthropogenic deposits exhibit a range of hydrogeological properties. Classifications of anthropogenic deposits required for applied research of this kind can be readily hosted by 3-D modelling, because it is underpinned by a borehole framework that can be coded according to the required output, providing that the material descriptions presented in the borehole logs is sufficiently detailed (Price et al., 2010). In areas that are rich with high-quality ground investigation data the technique offers the potential for further development in the potential application of domains to made ground.

The possibility of carrying out field work in order to validate the results of this work is being considered. The usefulness of field validation is debatable as the IST is intended to be a screening tool for identifying the potential for pollutant linkages to exist rather than determining that the pollutant linkages exist in reality. As a planning tool, field investigation would be used in the case of two or more sites scoring equally, in order to distinguish between them.

In the context of the Olympic Park site the tool has been designed to satisfy the requirements of UK planning legislation. It is considered that comparable approaches could be taken to address aspects of European legislation, for example Integrated Pollution and Control (Directive 96/61/EC), or the Water Framework Directive (2000/60/EC). In the context of the former consideration might also be given to atmospheric contaminant flow paths. In the context of the Water Framework Directive 
this methodology provides a potential tool to assist in River Basin Management planning.

\section{References.}

Aller L, Bennett T, Lehr JH, Petty RJ, Hackett G (1987) DRASTIC: a standardized system for evaluating ground water pollution potential using hydrogeologic settings. NWWA/EPA Series. EPA-600/2-87-035.

Ander EL, Quigley S, Lawley RS, Marchant AP, Smith BM Brown MJ, Fiorini E, Hooker PJ (2003) ConSEPT: an integrated GIS methodology for the prioritisation of potentially contaminated land (issue 1.0). British Geological Survey, IR/03/025c. 132pp.

Canter LW, Knox RC, Fairchild DM (1987) Ground water quality protection. Lewis Publishers, Inc. 562pp.

Department for Environment Food and Rural Affairs and Environment Agency (2002a) Assessment of risks to human health from land contamination. An overview of the development of soil guideline values and related research. CLR 7. (Bristol: Environment Agency).

Department for Environment Food and Rural Affairs and Environment Agency (2002b) Potential contaminants for the assessment of land. CLR 8. (Bristol: Environment Agency).

Department of the Environment (1995) Prioritisation and categorisation procedure for sites which may be contaminated. CLR 6.

Edmonds CN (1983) Towards the prediction of subsidence risk upon the Chalk outcrop. Quarterly Journal of Engineering Geology, London, 16, 261-266.

Edmonds CN, Green CP, Higginbottom IE (1987) Subsidence hazard prediction for limestone terrains as applied to the English Cretaceous Chalk. Planning and Engineering Geology. Ed. Culshaw, M.G., Bell, F.G., Cripps, J.C. and O' Hara, M. Volume 4. The Geological Society: London, 283-293.

Ellison RA (2004) Geology of London. Special Memoir for 1: 50000 Geological sheets 256 (North London), 257 (Romford), 270 ( South London) and 271 (Dartford) (England and Wales). British Geological Survey.

Environment Agency (2001) Piling and Penetrative round Improvement Methods on Land Affected by Contamination: Guidance on Pollution Prevention. $\mathrm{NC} / 99 / 73$.

Gilman J (2003) Tools for the job. Environmental Health Journal (April, 2003), 104196.

Huchinson RN (1989) Possible late Quaternary pingo remnants in central London. Nature, 284, 253-255.

Lloyd T, Foster S, Morris BHllK, Robinson R, Aldous P, Hart A (1998) Chapter 4: Assessment of contamination risk for ground water resources. In: Department of the Environment, Transport and the Regions and Department of Health. Cryptosporidium in Water Supplies. Third Report of the Group of Experts chaired by Prof. I. Bouchier. p 26-42.

Lelliott M, Bridge, D McC, Kessler H, Price SJ, Seymour KJ (2006). The application of 3D geological modelling to aquifer recharge assessments in an 
urban environment. Quarterly Journal of Engineering Geology and Hydrogeology 39, No. 3, 293-302.

MacDonald AM, Allen DJ (2001) Aquifer properties of the Chalk of England.

Quarterly Journal of Engineering Geology and Hydrogeology. 34 (4): 371 384.

Marsland PA, Carey MA (1999) Methodology for the Derivation of Remedial Targets for Soil and Groundwater to Protect Water Resources. Environment Agency Research and Development Publication 20. 89 pp.

McMillan AA, Powell JH (1999) BGS Rock Classification Scheme Volume 4. Classification of artificial (man-made) ground and natural superficial deposits - applications to geological maps and datasets in the UK. BGS Research Report RR99-04.

McMillan AA, Heathcote JA, Klinck BA, Shepley MG, Jackson CP, Degnan PJ (2000) Hydrogeological characterization of the onshore Quaternary sediments at Sellafield using the concept of domains. Quarterly Journal of Engineering Geology and Hydrogeology, 33, 301-323.

Ó Dochartaigh BÉ, MacDonald AM, Griffiths KJ, Lilly A, DeGroote J, Chilton PJ, Hughes AG (2009) Assessing the effectiveness of Scotland's groundwater nitrate monitoring network. Quarterly Journal of Engineering Geology and Hydrogeology, 40, 4, 293-406.

Price SJ, Burke HF, Terrington RL, Reeves HJ, Boon DP, Scheib AJ (2010) The 3D characterisation of the zone of human interaction and the sustainable use of underground space in urban and peri-urban environments : case studies from the UK: In: Zeitschrift der Deutschen gesellschaft fur geowissenschaften Vol. 161 pt/no 2 (2010) p. 219-235 Article

Royse KR (2005) Can sustainable development be achieved when geoscience issues are ignored? In 4th global conference: Environmental justice and global citizenship 'environment, sustainability and technology'.

Royse KR, Price S, Entwistle D, Lelliott M, Terrington R (2005) Thames Gateway Pilot Study, Results: Is there a need for Urban Geoscience in the Gateway? British Geological Survey. 35pp.

Royse K, Rutter H, Entwisle D (2009) Property attribution of 3D geological models in the Thames Gateway, London : new ways of visualising geoscientific information. Bulletin of Engineering Geology and the Environment, 68 (1). 116. 10.1007/s10064-008-0171-0.

Sumbler MG (1996) British regional geology: London and the Thames Valley $\left(4^{\text {th }}\right.$ Edition). London HMSO. 173pp.

Waters CN, Price SJ, Hawkins MP, Marchant AP, Fiorini E, Brown SE, Tye AM, Fleming C, Davies J, Schofield DI, Barclay WJ, Garcia-Bajo M. (2006) A background to urban geoscience studies in Swansea-Neath-Port Talbot area. British Geological Survey Internal Report, IR/05/073R. 80pp.

Weinreb B, Hibbert C (1995) The London Encyclopaedia. Macmillan Reference Books. 1060pp. 